Autologous transfusion does not provide a cheaper alternative to transfusion of allogeneic blood. The cost of producing a unit of autologous blood in our centre is currently about twice the cost of an equivalent allogeneic unit. This difference is due to the staffing and transport costs of the autologous clinics, which are located at several hospitals within the region to allow easy access for patients. If the programme were to expand, allowing venesection of more donors at each clinic, the collection cost per unit would fall.

Unused autologous units were not made available for any other recipient. Most of our autologous donors were taking drugs which would make their blood donation unacceptable for allogeneic use. Also, most autologous units were transfused, those not transfused being held for potential autologous use until expiry or patient discharge. Thus very few units would ultimately be suitable for crossover and procedures for their retrieval are not justified.

We have shown the feasibility of a regional autologous donation programme coordinated by a blood transfusion centre. Main factors which prevented autologous donation were failure to attend the clinic, anaemia, and cardiovascular disease. The main factors which restricted the provision of blood by those who donated were late referral and post-donation anaemia. The aim of avoiding allogeneic blood transfusion was achieved by most patients who donated blood.

We are grateful to the Northern Regional Health Authority for funding and thank all clinicians who entered patients into the programme. We also thank Dr J Conn, Dr J Liston, Dr S Rusby, Sister P O'Brien, Staff Nurse F Jackson, Staff Nurse H Genalis, Mrs C Jefferies, Mrs P Lander, and Mrs S Masterman; the staff of all departments of the Northern Region Blood Transfusion Service; the staff of participating hospital blood banks; and $\mathrm{Mr} \mathrm{D}$ Robinson, of Conway Robinson Associates, for statistical advice.

1 Dodd RY. The risk of transfusion transmitted infection. $N$ Engl $7 \mathrm{Med}$ 1992;327:419-20

2 Petersen LR, Satten G, Dodd RY. Current estimates of the infectious window period and risk of HIV infection from seronegative blood donations. In: Programe and abstracts of the fifth national forum on AIDS, hepatitis and other blood-borne diseases, Atlanta, March 330, 1992. Princeton, New Jersey Symedco, 1992:37.

3 Nelson K, Donahue J, Munoz A, Ness P, McAllister H, Yawn D, et al. Risk of transfusion-transmitted HIV1 and HTLV1/2 [abstract]. Transfusion 1991 31(suppl 85):47S

4 Busch MP, Eble EB, Khayam-Bashi H, Heilbron D, Murphy EL, Kwok S et al. Evaluation of screened blood donations for human immunodeficiency virus type 1 infection by culture and DNA amplification of pooled cells. NEngl f Med 1991;325:1-5.

5 Hickman M, Mortimer JY, Rawlinson VI. Donor screening for HIV: how many false negatives? Lancet 1988;i:1221.

6 Ward JW, Holmberg SD, Allen JR, Cohn DL, Critchley SE, Kleinman SH, et al. Transmission of human immunodeficiency virus (HIV) by blood et al. Transmission of human immunodeficiency virus (HIV) by blood 1988;318:473-8.

7 Gunson HH, Rawlinson VI. Screening of blood donations for HIV-1 antibody: 1985-1991. Communicable Disease Report 1991;1:R144-6.

8 Donahue JG, Munoz DVM, Ness PM, Brown DE Jr, Yawn DH, McAllister $\mathrm{HA}$, et al. The declining risk of post-transion hepatitis $\mathrm{C}$ virus infection. $N$ Engl f Med 1992;327:369-73.

9 Giblett ER. Blood group alloantibodies: an assessment of some laborator practices. Transfusion 1977;17:299-308.

10 Popovsky MA, Chaplin HC, Moore SB. Transfusion-related acute lung injury: a neglected, serious complication of hemotherapy. Transfusion 1992;32: $589-92$

11 British Committee for Standardisation in Haematology, Blood Transfusion Task Force. Guidelines for autologous transfusion. Clin Lab Haematol 1988;10:193-201

12 Committee of Experts on Blood Transfusion and Immunohematology. Council of Europe guidelines for autologous blood transfusion. Vox Sang 1989;57 of Europe

13 Council on Scientific Affairs. Autologous blood transfusions. FAMA 1986; 256:2378-80.

14 Kruskall MS, Glazer EE, Leonard SS, Willson SC, Pacini DG, Donovan LM et al. Utilization and effectiveness of a hospital autologous pre-operative blood donor program. Transfusion 1986;26:335-40.

15 Au Bachon JP, Popovsky MA. The safety of pre-operative autologous donation in the non-hospital setting. Transfusion 1991;31:513-7.

16 Benoit P, Marchand S, Decary F. Blood donation by people aged 70 and over Transfusion Medicine 1992;2:75.

17 Pindyck J, Avorn J, Kuriyan M, Reed M, Iqbal MJ, Levine SJ. Blood

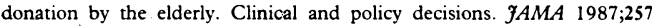
1186-8.

18 Schmidt PJ. Blood donation by the healthy elderly. Transfusion 1991;31:681-3. 19 Goodnough LT, Rudnick S, Price TH, Ballas SK, Collins ML, Crowley JP, et al. Increased pre-operative collection of autologous blood with recombinant human erythropoietin therapy. $N$ Engl f Med 1989;321: $1163-8$.

20 Graf $\mathrm{H}$, Watzinger $\mathrm{U}$, Ludvik B, Wagner A, Hocker P, Zweymuller KK Recombinant human erythropoietin as adjuvant treatment for autologous Recombinant human erythropoietin as

21 Tasaki T, Ohto H, Hashimoto C, Abe R, Saitoh A, Kikuchi S. Recombinan human erythropoietin for autologous blood donation: effects on perioperative red-blood-cell and serum erythropoietin production. Lance 1992;339:773-5.

22 Toy PTCY, Strauss RG, Stehling LC, Sears R, Price TH, Rossi EC, et al. Predeposited blood for elective surgery. $N$ Engl f Med 1987;316:517-20.

(Accepted 6 October 1992)

\section{Servizio di}

Immunoematologia e

Trasfusionale, Ospedale S Croce, USL 58, Cuneo, Italy

G M Peano, deputy consultant in transfusion medicine G Menardi, consultant biologist

$\mathrm{R}$ Balbo, męmber of blood bank unit medical staff

D Marenchino, member of blood bank unit medical staff $S$ Fenoglio, chief of blood bank unit

I Divisione di Medicina Generale, Clinica Medica B, Università di Torino, Italy L M Fenoglio, research fellow, gastroenterologist

Correspondence to: Dr Gian Michele Peano, Via Q Sella 22, 12100 Cuneo, Italy.

$B M \mathcal{1}$ 1992;305:1473-4

\section{Heterosexual transmission of hepatitis $\mathbf{C}$ virus in family groups without risk factors}

\author{
G M Peano, L M Fenoglio, G Menardi, R Balbo, \\ D Marenchino, S Fenoglio
}

Alter et al reported finding antibodies to hepatitis C virus (anti-HCV) in most patients with post-transfusion non-A non-B hepatitis. ' Similar findings have been recorded in patients having haemodialysis and in drug misusers. Furthermore, hepatitis $C$ virus may also be detected in patients with chronic liver disease, hepatocellular carcinoma, and chronic alcoholism who have no history of blood transfusions, and variable rates of infection have been recorded in healthy blood donors. We may therefore surmise that risk factors other than direct blood transmission exist. Hepatitis $C$ virus may be transmitted by sexual intercourse. ${ }^{23}$ Other studies, however, have failed to confirm this or shown that it occurs only rarely. ${ }^{45}$

Many of these studies were carried out on heterogeneous groups (homosexuals, drug misusers, haemophilic patients, family groups, etc), so that we still lack conclusive results. We report the role of heterosexual activity and of household contacts in the spread of hepatitis C.virus as determined by studying viral markers in partners and other family members of anti-HCV positive blood donors without known risk factors.

\section{Subjects, methods, and results}

Eighty six blood donors (49 men) were evaluated based on the following criteria: presence of anti-HCV; absence of hepatitis B surface antigen and anti-HIV; no history of drug abuse; in a stable heterosexual relationship (range eight months to 40 years). The subjects were studied in two groups, group 1 being separated into subgroups $1 \mathrm{a}$ and $1 \mathrm{~b}$. Subgroup $1 \mathrm{a}$ comprised 29 cases ( 16 men) of hepatitis $C$ virus related chronic hepatitis confirmed histologically or from a history of increased serum alanine aminotransferase values (above $60 \mathrm{IU} / \mathrm{l}$ ) for more than six months. Subgroup $1 \mathrm{~b}$ comprised 14 subjects (eight men) with a chance finding of abnormal serum alanine aminotransferase activity in the absence of evidence of liver disease. Group 2 comprised 43 subjects ( $25 \mathrm{men}$ ) without a clinical history of liver disease or enzyme abnormality. Sixty eight randomly selected anti-HCV negative blood donors (40 men) served as controls (group 3). Other criteria for selection as controls were as in groups 1 and 2.

Blood donors' partners ( $n=154 ; 65$ men), who were negative for HIV, had no history of drug abuse or other known risk factors, and engaged only in heterosexual activity, were accepted after accurate history taking 
and clinicoserological evaluation. Mean ages of donors and partners were: group $1,52.6$ and 51.9 years; group $2,48.0$ and 47.4 years; and group $3,46.3$ and $46 \cdot 8$ years.

All serum samples tested for alanine aminotransferase activity, hepatitis B surface antigen, and anti-HIV were screened with Abbott hepatitis $C$ virus enzyme immunoassay, second generation kit. In group 1, 10 partners (six men) tested anti-HCV positive, and in group 2 three partners (two men) tested positive Among the partners of controls one woman tested anti-HCV positive (table). (This last result $(1.5 \%)$ is

Prevalence of anti-HCV positive subjects in groups $1-4^{*}$

\begin{tabular}{llllllll}
\hline & 1 & $1 \mathrm{a}$ & $1 \mathrm{~b}$ & 2 & 3 & 4 \\
\hline $\begin{array}{l}\text { No anti-HCV } \\
\text { negative }\end{array}$ & 33 & 22 & 11 & 40 & 67 & 23 \\
$\begin{array}{l}\text { No }(\%) \text { anti-HCV } \\
\text { positive }\end{array}$ & $10(23 \cdot 3)$ & $7(24 \cdot 1)$ & $3(21 \cdot 4)$ & $3(7 \cdot 0)$ & $1(1 \cdot 5)$ & 0 \\
\hline Total & 43 & 29 & 14 & 43 & 68 & 23 \\
\hline
\end{tabular}

$\chi$ Test (three degrees of freedom) $19 \cdot 8 ; p<0.0005$

${ }^{\star}$ Group 1: heterosexual partners of anti-HCV positive blood donors with chronic liver disease (subset 1a) or previously abnormal alanine wiming chronict anti-HCV positive donors without previously known abnat parners of anti-HCV positive donors alanine random anti-HCV negative donors); group 4: children or other family members of anti-HCV positive subjects.

consistent with findings in Piedmont among people of the same age range. Serum samples from the 14 partners positive for anti-HCV were tested with a recombinant immunoblot assay (Ortho) capable of detecting antibodies to antigens 5-1-1, c-100-3, c22-3, and $\mathrm{c} 33 \mathrm{c}$. All gave positive results with at least two antigens. Identical antigenic specificities were observed in seven of the 13 couples in whom both partners were anti-HCV positive.

Among 23 children or other family members of anti-HCV positive subjects (group 4; mean age
14.3 years) none ( 15 in group 1 families, eight in group 2) tested positive (table)

\section{Comment}

These results suggest that heterosexual intercourse may be an important route of transmission of $\mathrm{HCV}$. W The risk of virus transmission when a partner in a couple without other risk factors is anti-HCV positive may increase with a worsening liver condition. This risk is high when patients have hepatitis $C$ virus related chronic hepatitis whereas in subjects without biochemical evidence of liver disease the risk seems three times smaller-though nearly five times greater 8 than in controls.

Serum samples were not tested with polymerase chain reaction, the subjects being distinguished only by clinical and biochemical data. Nevertheless, we $\vec{\omega}$ suggest that our group 2 corresponded to patients (believed to be nearly half of cases) in whom hepatitis $\mathrm{C}$ does not evolve as a chronic condition.

More information is needed about the relation between the presence of anti-HCV and infectivity as $\sigma$ well as infectivity in different phases of $\mathrm{HCV}$ infection.

1 Alter HJ, Purcell RH, Shih Jw, Melpolder JC, Houghton M, Choo QL, et al Detection of antibodies to hepatitis $C$ virus in prospectively followed $\mathrm{C}$ transfusion recipients with acute and chronic non-A, non-B hepatitis. $N$ Engl transfusion recipients with acute and chronic non-A, non-B hepatitis. N Engl $\mathrm{O}$

2 Alter MJ, Coleman PJ, Alexander WJ, Kramer E, Miller JK, Mandel E, et al. $\vec{N}$ Importance of heterosexual activity in the transmission of hepatitis $B$ and $N$ non-A, non-B hepatitis. IAMA 1989;262:1201-5.

3 Tedder RS, Gilson RJC, Briggs M, Loveday C, Cameron CH, Garson JA, et al. Hepatitis C virus: evidence for sexual transmission. BMF 1991;302: 1299-302.

4 Kiyosawa K, Sodeyama T, Tanaka E, Shimizu S, Furuta S, Miyazaki Y, et al. Z Intrafamilial transmission of hepatitis $\mathrm{C}$ virus in Japan. $\mathrm{f}$ Med Virol 1991;33:114-6.

5 Melbye M, Biggar RJ, Wantzin P, Krogsgaard K, Ebbesen P, Becker NG. Sexual transmission of hepatitis $C$ virus: cohort study (1981-9) among $N$ European homosexual men. BMF 1990;301:210-2.

(Accepted 8 September 1992)

\section{Acute compartment syndromes resulting from anticoagulant treatment}

\author{
S M Hay, M J Allen, M R Barnes
}

Leicester Royal Infirmary, Leicester LE1 5WW S M Hay, orthopaedic registrar $\mathrm{MJ}$ Allen, accident and emergency consultant M R Barnes, senior physicist

Correspondence to: Mr Allen.

BMF 1992;305:1474-5
Anticoagulants are commonly used both prophylactically and to treat venous thrombosis. Because such treatment increases a patient's susceptibility to haemorrhage comparatively minor trauma may result in disproportionate intracompartmental bleeding and the development of a compartment syndrome. This requires prompt diagnosis and rapid treatment to avert a potential disaster. Compartment syndromes have been reported in association with anticoagulants, but always after arterial puncture for blood gas analysis..$^{1-4}$ To heighten awareness of this potential complication we report seven cases of compartment syndrome after minor trauma in patients who received anticoagulant treatment.

\section{Case reports}

The table gives details of the seven cases. Four patients were taking anticoagulants when the minor trauma occurred, and three were given them after the trauma occurred because venous thrombosis was diagnosed erroneously. In only one case was the dosage of anticoagulant above the normal therapeutic range for the particular clinical indication. In the six cases in which compartmental pressures were measured the slit catheter technique was used as described by Barnes et al. ${ }^{5}$

Four of the seven patients underwent urgent fasciotomy, and only one had permanent postoperative $\frac{5}{3}$ nerve damage and muscle necrosis. In this case compartmental pressure was not measured until three 8 days after the trauma. In case 1 no action was taken because the compartmental pressure was not particu- 응 larly high $(58 \mathrm{~mm} \mathrm{Hg})$ and was falling. In case 5 blood $N$ flowed freely from within the compartment when a catheter was inserted to measure the pressure; aspiration of $65 \mathrm{ml}$ blood reduced the pressure to normal so $\bar{N}$ that surgery was avoided. In case 7 the patient 0 presented 12 days after injury for a surgical opinion. $\omega$ Foot drop had been established for several days and it $<$ was considered too late for fasciotomy.

All the injuries were minor, either being pulled $\mathbb{D}$ muscles or resulting from everyday impacts, but were sufficiently severe for the patients to present at the ${ }^{0}$ accident and emergency department. None of these patients suffered the type of fracture or major soft tissue injury that is normally associated with an acute compartment syndrome.

\section{Comment}

The complication of anticoagulant treatment des-? cribed is not common, but the disabling effects of untreated or late treated compartment syndrome justify vigilance at all times by the attendant clinician. 